\title{
Paper-Based Electrochemical Detection of Chlorate
}

\author{
Lisa C. Shriver-Lake, Dan Zabetakis, Walter J. Dressick, David A. Stenger and Scott A. Trammell * \\ U.S. Naval Research Laboratory, Center for Bio/Molecular Science \& Engineering (Code 6900), \\ 4555 Overlook Avenue SW, Washington, DC 20375, USA; lisa.shriverlake@nrl.navy.mil (L.C.S.-L.); \\ daniel.zabetakis@nrl.navy.mil (D.Z.); walter.dressick@verizon.net (W.J.D.); david.stenger@nrl.navy.mil (D.A.S.) \\ * Correspondence: scott.trammell@nrl.navy.mil; Tel.: +1-202-404-6063
}

Received: 21 November 2017; Accepted: 19 January 2018; Published: 24 January 2018

\begin{abstract}
We describe the use of a paper-based probe impregnated with a vanadium-containing polyoxometalate anion, $\left[\mathrm{PMo}_{11} \mathrm{VO}_{40}\right]^{5-}$, on screen-printed carbon electrodes for the electrochemical determination of chlorate. Cyclic voltammetry $(\mathrm{CV})$ and chronocoulometry were used to characterize the $\mathrm{ClO}_{3}{ }^{-}$response in a $\mathrm{pH}=2.5$ solution of $100 \mathrm{mM}$ sodium acetate. A linear $\mathrm{CV}$ current response was observed between 0.156 and $1.25 \mathrm{mg} / \mathrm{mL}$ with a detection limit of $0.083 \mathrm{mg} / \mathrm{mL}$ $(\mathrm{S} / \mathrm{N}>3)$. This performance was reproducible using $\left[\mathrm{PMo}_{11} \mathrm{VO}_{40}\right]^{5-}$-impregnated filter paper stored under ambient conditions for as long as 8 months prior to use. At high concentration of chlorate, an additional catalytic cathodic peak was seen in the reverse scan of the CVs, which was digitally simulated using a simple model. For chronocoulometry, the charge measured after 5 min gave a linear response from 0.625 to $2.5 \mathrm{mg} / \mathrm{mL}$ with a detection limit of $0.31 \mathrm{mg} / \mathrm{mL}(\mathrm{S} / \mathrm{N}>3)$. In addition, the slope of charge vs. time also gave a linear response. In this case the linear range was from 0.312 to $2.5 \mathrm{mg} / \mathrm{mL}$ with a detection limit of $0.15 \mathrm{mg} / \mathrm{mL}(\mathrm{S} / \mathrm{N}>3$ ). Simple assays were conducted using three types of soil, and recovery measurements reported.
\end{abstract}

Keywords: chlorate; electrochemical detection; paper-based probe; electrocatalysis; polyoxometalates

\section{Introduction}

We are developing inexpensive, miniaturized, low-power electrochemical sensors for incorporation into autonomous unmanned aerial vehicles (UAVs), with the goal to identify explosives as well as their precursors and degradation products in the field [1-3]. Electroanalytical chemistry is a promising field in which instrumentation and assays can be further developed for the detection of explosives associated with improvised explosive devices (IEDs) and their manufacturing facilities. As current detection methods for nitrogen-based explosives improve, in terms of sensitivity and selectivity [4-8], focus is shifting to alternative explosives that are based on chlorates or peroxides [9].

Spectrophotometric methods for chlorate detection are currently amenable for field use. These methods are generally based on bleaching the color of a dye species [10-14] in the presence of chlorate and form the concept of commercial test kits. The color change may be visible to the naked eye or with the aid of very simple instrumentation, permitting development of a lightweight system that requires little or no power to operate. However, there remain specificity/selectivity issues since some of these colorimetric tests can respond to other oxidants.

Recent advances in electronics miniaturization and design can now provide lightweight, low-cost, rugged, low-power potentiostats [3,15], allowing electrochemical methods that exploit the redox behavior of the chlorate species to provide a more convenient alternative to spectrophotometric detection methods. Stopped-flow injection methods using amperometric or spectrometric techniques have been reported for the detection of chlorate in soil samples [16,17], and the catalytic electroreduction of chlorate by polyoxometalates has been demonstrated [18]. 
Polyoxometalates (POMs) are polyatomic anions formed from transition metal oxyanions linked together by their oxygen atoms into three-dimensional structures. The transition metal atoms are in their high oxidation states and can include $\mathrm{Mo}, \mathrm{W}, \mathrm{V}, \mathrm{Nb}$, or Ta. POMs have been studied as electrocatalysts $[19,20]$, and in the case of polyoxotungstates and polyoxomolybdates the substitution of Mo or W by $\mathrm{V}$ increases the structure's stability at higher $\mathrm{pH}$ and allows for the "tuning" of their electrochemical properties [19,21-23]. POMs are catalytic for the reduction of chlorate, and we have recently described the use and characterization of a multilayer film, prepared via layer-by-layer deposition of cationic para-rosaniline acetate dye and the vanadium-containing polyoxometalate anion, $\left[\mathrm{PMo}_{11} \mathrm{VO}_{40}\right]^{5-}$, on indium tin oxide (ITO) as an electrode for determination of chlorate [1].

To miniaturize and modify the probe for incorporation into UAVs, we have taken advantage of paper-based electroanalytical chemistry combined with commercial screen-printed electrodes to construct simple probes for use in the field. The commercial screen-printed electrodes contain all three electrodes, i.e., the working, counter, and reference electrodes, needed for the major electroanalytical techniques, and are inexpensive, small, and robust enough for field work. The addition of the filter paper provides the volume for the electrolyte, making a practical thin layer cell for electrochemical detection. The paper can also serve as a filter for soil sampling or as a wipe for trace analysis. Here, the construction and demonstration of a simple paper-based/screen-printed electrode probe for the detection of chlorate in a variety of soil types is reported.

\section{Materials and Methods}

\subsection{Materials}

Ultrapure water of $18.2 \mathrm{M} \Omega \cdot \mathrm{cm}^{-1}$ resistivity obtained from a Milli-Q Advantage deionized water system was used to prepare all solutions and for all experiments. All chemicals were used as received. Sodium acetate, potassium chlorate, sodium chloride, potassium nitrate, sodium nitrite and sodium nitrate were all from Sigma-Aldrich Chemicals. $\mathrm{Na}_{4} \mathrm{H}\left[\mathrm{PMo}_{11} \mathrm{VOO}_{40}\right]$ was prepared with some modification of an earlier literature method [24] at a reduced scale recently reported in Trammell et al. [1]. Certified soil types where purchased from Sigma-Aldrich Chemicals.

\subsection{Measurements}

All electrochemical measurements were made under ambient, aerobic conditions. The cyclic voltammetry (CV), chronoamperometry, and chronocoulometry measurements were performed using a three-electrode configuration with a model 760 electrochemical workstation from $\mathrm{CH}$ Instruments. Screen-printed electrodes containing a carbon working electrode with a diameter of $2 \mathrm{~mm}$, a carbon counter electrode, and a $\mathrm{Ag} / \mathrm{AgCl}$ reference electrode were purchased from Pine Research Instrumentation. Digital simulations of the $\mathrm{CV}$ s were made with the $\mathrm{CH}$ Instruments software using a diffusive model with diffusion coefficients at $1 \times 10^{-5} \mathrm{~cm}^{2} / \mathrm{s}$ and Butler-Volmer kinetics with alpha set to 0.5 .

\subsection{Paper-Based Electrochemical Probe}

A solution of $1 \mathrm{mg} / \mathrm{mL}\left[\mathrm{PMo}_{11} \mathrm{VO}_{40}\right]^{5-}$ was prepared in a buffer containing $100 \mathrm{mM}$ sodium acetate adjusted to $\mathrm{pH} 2.5$ with concentrated $\mathrm{HCl}$. An aliquot of the $\left[\mathrm{PMo}_{11} \mathrm{VO}_{40}\right]^{5-}$ solution $(50 \mu \mathrm{L})$ was added to a strip of Whatman \#4 filter paper cut to dimension of approximately $1 \mathrm{~cm} \times 1 \mathrm{~cm}$. The paper was allowed to air dry and stored dry at room temperature until further use. For the electrochemical measurements, a single piece of filter paper containing $\left[\mathrm{PMo}_{11} \mathrm{VO}_{40}\right]^{5-}$ was placed on top of a screen-printed electrode and $50 \mu \mathrm{L}$ of sodium acetate $(100 \mathrm{mM}, \mathrm{pH} 2.5)$ solution was added to the paper. For the chlorate dose-response, an additional $50 \mu \mathrm{L}$ of potassium chlorate stock solution in sodium acetate $(100 \mathrm{mM}, \mathrm{pH} 2.5)$ was added to the paper on top of the probe after 3 complete potential sweeps ( 0 to $-1.0 \mathrm{~V}$ vs. $\mathrm{Ag} / \mathrm{AgCl}$ and reversed) to equilibrate the paper-based probe and obtain a 
background signal. A total of 15 complete sweeps at $100 \mathrm{mV} / \mathrm{s}$ were run for each test sample, by which time the current had stabilized; the current was then read and recorded.

\subsection{Soil Assay}

To $100 \mathrm{mg}$ of each soil type (clay, sand, loam soil), $100 \mu \mathrm{L}$ of $2.5 \mathrm{mg} / \mathrm{mL}$ potassium chlorate in $100 \mathrm{mM}$ sodium acetate $\mathrm{pH} 2.5$ were added, and this mixture was placed under a stream of nitrogen until dry. For the assay, filter paper impregnated with the $\left[\mathrm{PMo}_{11} \mathrm{VO}_{40}\right]^{5-}$ as above was placed on the electrode and wetted with $90 \mu \mathrm{L}$ of acetate buffer. After 3 complete sweeps to equilibrate the paper-based probe and obtain a background signal, the dried soil was placed on top of the filter paper and another $90 \mu \mathrm{L}$ of acetate buffer were added to fully saturate the soil samples. A total of 15 complete sweeps were run for each test sample to reach a stabilized current, after which the current was recorded as the response.

\section{Results and Discussion}

\subsection{Detection of Chlorate}

The construction of a paper-based electrochemical probe containing the $\left[\mathrm{PMo}_{11} \mathrm{VO}_{40}\right]^{5-}$ catalyst is simple and convenient when combined with screen-printed electrodes. A schematic is shown in Scheme 1. The filter paper containing the catalyst was cut into small strips that cover the electrode surface of the commercial screen-printed electrodes, and, with the addition of a small amount of buffer, the paper-based/screen-printed electrode became electrochemically active.
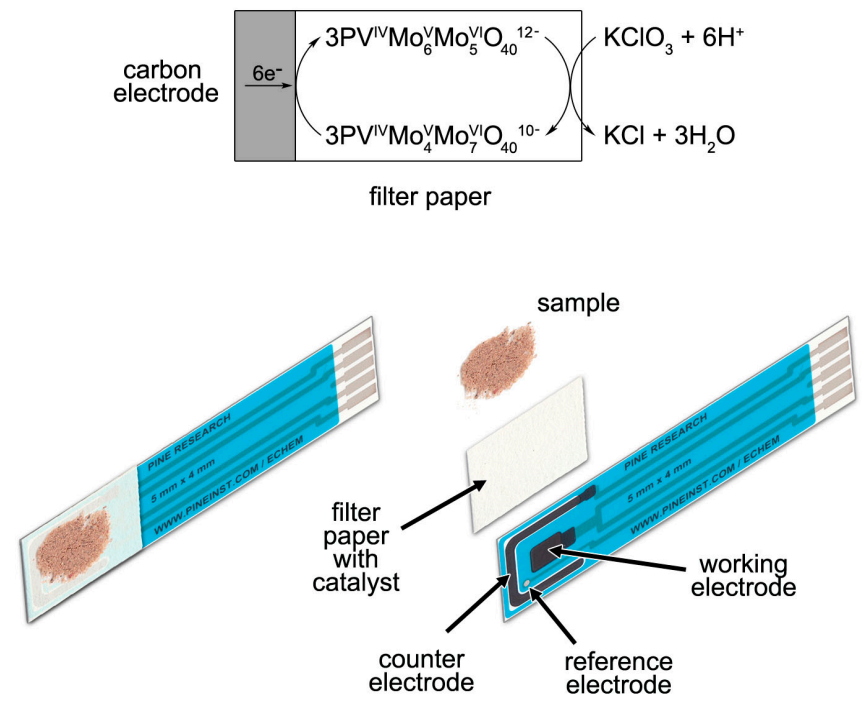

Scheme 1. Paper-based electrochemical detection of chlorate.

To characterize the electrochemical response of our paper-based probe, we used CV and chronocoulometry. As shown in Figure 1A, the CV of the paper-based/screen-printed electrode revealed a single redox peak at $\mathrm{E}_{\mathrm{pc}}=-0.70 \mathrm{~V}$ vs. $\mathrm{Ag} / \mathrm{AgCl}$ assigned to the reduction of the $\left[\mathrm{PMo}_{11} \mathrm{VO}_{40}\right]^{5-}$ in the filter paper. The peak is broad and on a sloping background. The response is notably different from our earlier report of the layer-by layer system in which several well defined peaks are seen in the CVs [1]. In the earlier study, the electrode was directly modified with a film containing the catalyst. In the paper-based approach, the $\left[\mathrm{PMo}_{11} \mathrm{VO}_{40}\right]^{5-}$ catalyst needed to diffuse to the electrode through the paper. The redox couple grows in after the addition of buffer and increases with scan number reaching a stable signal after 5 min.

The addition of $\mathrm{KNO}_{3}$ or $\mathrm{NaNO}_{3}$ had little effect on the CVs as shown in Figure 1A; however, with the addition of $\mathrm{KClO}_{3}$, there was a pronounced catalytic response at the cathodic peak. This peak 
grew as scan number increased, reaching a stable signal at 15 scans. The strong catalytic wave corresponds to the $\mathrm{pH}$-dependent catalyzed reduction of chlorate to chloride, as shown in Scheme 1. Two one-electron reductions of $\mathrm{Mo}^{\mathrm{VI}}$ components of the $\left[\mathrm{PMo}_{11} \mathrm{VO}_{40}\right]^{5-}$ species generate the $\mathrm{Mo}^{\mathrm{V}}$ oxidation state product, which is capable of reducing chlorate to chloride under acid conditions. The oxidized $\mathrm{PV}^{\mathrm{IV}} \mathrm{Mo}_{4}{ }^{\mathrm{V}} \mathrm{Mo}_{7}{ }^{\mathrm{VI}} \mathrm{O}_{40}{ }^{10-}$ species produced is identical to the species serving as reactant. At the applied electrode potential, it is immediately reduced once again to $\mathrm{PV}^{\mathrm{IV}} \mathrm{Mo}_{6}{ }^{\mathrm{V}} \mathrm{Mo}_{5}{ }^{\mathrm{VI}} \mathrm{O}_{40}{ }^{12-}$ and reacts with additional chlorate to continue the catalytic cycle.
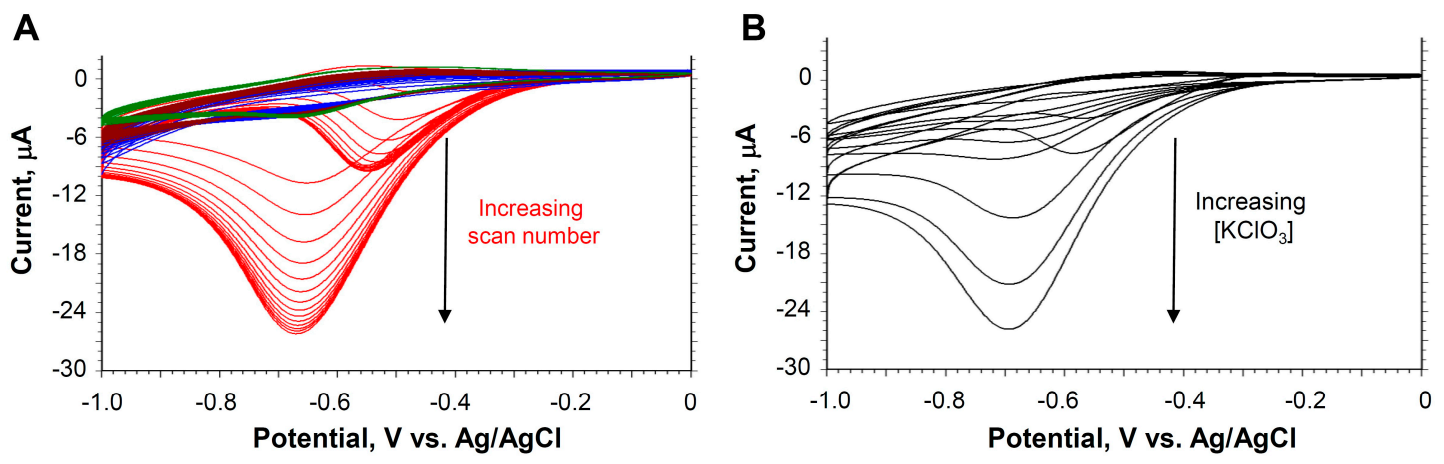

Figure 1. (A) Cyclic voltammograms with increasing scan number at $100 \mathrm{mV} / \mathrm{s}$ for the paper-based electrochemical probe containing $0.05 \mathrm{mg}\left[\mathrm{PMo}_{11} \mathrm{VO}_{40}\right]^{5-}$ in $100 \mu \mathrm{L}$ of buffer. Background (blue), $\mathrm{NaNO}_{3}$ (brown), $\mathrm{KNO}_{3}$ (green), $\mathrm{KClO}_{3}$ (red) all at $5 \mathrm{mg} / \mathrm{mL}$. (B) Cyclic voltammograms with increasing $\left[\mathrm{KClO}_{3}\right]$ from 0.078 to $5 \mathrm{mg} / \mathrm{mL}$.

Increasing the $\left[\mathrm{PMo}_{11} \mathrm{VO}_{40}\right]^{5-}$ catalyst in the paper decreased the time needed to reach a stable signal and increased the catalytic current. However, the cyclic voltammograms became distorted with the higher catalyst concentration, shifting the cathodic peak to potentials of more negative values with the $\mathrm{KClO}_{3}$ signal appearing beyond the switching potential as shown in Figure 2.

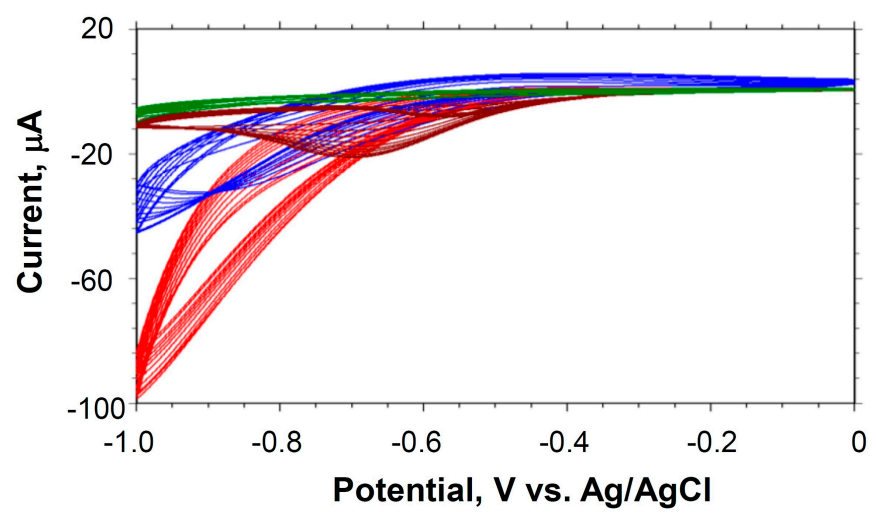

Figure 2. Cyclic voltammograms for the paper-based electrochemical probe in $100 \mu \mathrm{L}$ of buffer containing $0.05 \mathrm{mg}$ (green) of $\left[\mathrm{PMo}_{11} \mathrm{VO}_{40}\right]^{5-}$ and with $5 \mathrm{mg} / \mathrm{mL}$ of $\mathrm{KClO}_{3}$ (brown) or $0.4 \mathrm{mg}$ of $\left[\mathrm{PMo}_{11} \mathrm{VO}_{40}\right]^{5-}$ (blue) and with $5 \mathrm{mg} / \mathrm{mL}$ of $\mathrm{KClO}_{3}$ (red).

The catalytic response increased with increasing $\mathrm{KClO}_{3}$, as shown in Figure 1B. A plot of the dose-response curve, $\mathrm{I}_{\mathrm{pc}}$ vs. $\left[\mathrm{KClO}_{3}\right]$ is shown in Figure 3A, giving a linear range from 0.156 to $1.25 \mathrm{mg} / \mathrm{mL}$ with a detection limit of $0.083 \mathrm{mg} / \mathrm{mL}(\mathrm{S} / \mathrm{N}>3$ ) (Table 1 ).

Similar results within experimental error were observed for the $\left[\mathrm{PMo}_{11} \mathrm{VO}_{40}\right]^{5-}$-impregnated filter paper stored under ambient conditions for as long as 8 months (Figure 3B) prior to use, further attesting to the stability and reproducibility of our system. 
To investigate whether other techniques could improve the analytical response, chronocoulometry (Figure 4A) was investigated using total charge passed during $5 \mathrm{~min}$ or the slope (charge/s). A plot of the total charge passed at 5 min vs. $\left[\mathrm{KClO}_{3}\right]$ is shown in Figure $4 \mathrm{~B}$, giving a linear range from 0.625 to $2.5 \mathrm{mg} / \mathrm{mL}$ with a detection limit of $0.31 \mathrm{mg} / \mathrm{mL}(\mathrm{S} / \mathrm{N}>3)$. A plot of the final slope (mC/s) vs. $\left[\mathrm{KClO}_{3}\right]$ is also shown in Figure $4 \mathrm{C}$ with a linear range from 0.312 to $2.5 \mathrm{mg} / \mathrm{mL}$ and a detection limit of $0.15 \mathrm{mg} / \mathrm{mL}(\mathrm{S} / \mathrm{N}>3)$. Parameters for the different electroanalytical techniques are given in Table 1. Among the three cases, CV has the lowest LOD.
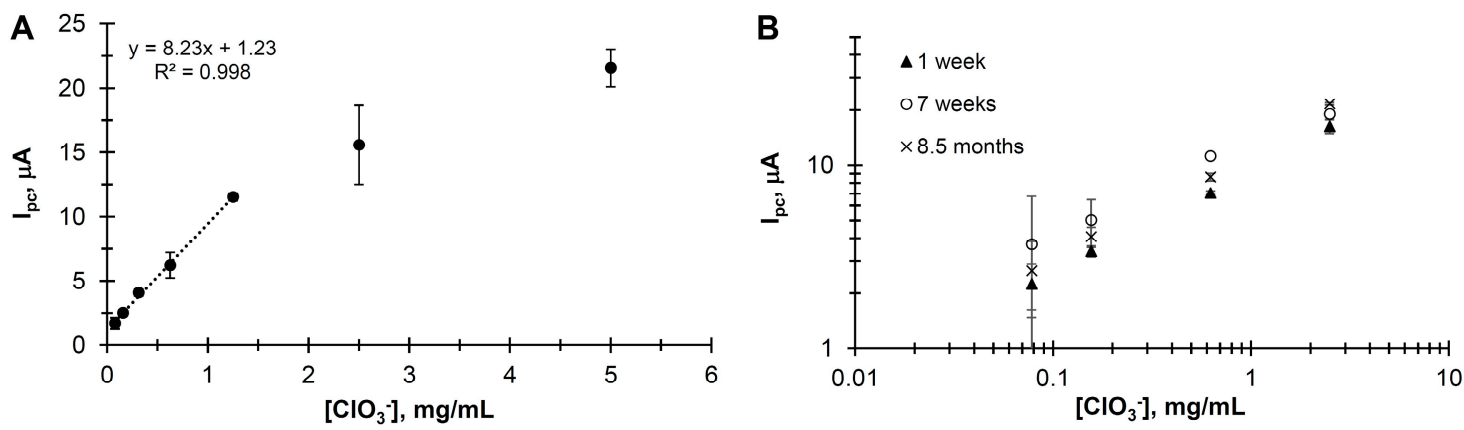

Figure 3. (A) Dose-response curve, $\mathrm{I}_{\mathrm{pc}}$ vs. $\left[\mathrm{KClO}_{3}\right]$. Parameters: Scan rate $=100 \mathrm{mV} / \mathrm{s}$; buffer $=100 \mu \mathrm{L}$ of $50 \mathrm{mM}$ sodium acetate adjusted to $\mathrm{pH} 2.5$ with $\mathrm{HCl}$; filter paper $=1 \mathrm{~cm}^{2}$ with $0.45 \mathrm{mg}$ of $\left[\mathrm{PMo}_{11} \mathrm{VO}_{40}\right]^{5-}$; electrodes = screen-printed carbon as working and counter with an $\mathrm{Ag} / \mathrm{AgCl}$ screen-printed reference. (B) Cyclic voltammetry (CV) dose-response of the paper-based electrochemical probe as a function of the age of the filter paper containing the catalyst.

Table 1. Analytical parameters for the detection of chlorate using a paper-based electrochemical probe containing $\left[\mathrm{PMo}_{11} \mathrm{VO}_{40}\right]^{5-}$.

\begin{tabular}{cccc}
\hline Electrochemical Technique & $\begin{array}{c}\text { Linear Range } \\
(\mathbf{m g} / \mathbf{m L})\end{array}$ & Sensitivity & LOD $^{\text {a }}(\mathbf{m g} / \mathbf{m L})$ \\
\hline Cyclic voltammetry, $\mathrm{I}_{\mathrm{pc}}$ vs. dose & $0.156-1.25$ & $8.2 \mu \mathrm{A} \mathrm{per} 1 \mathrm{mg} / \mathrm{mL}$ & 0.083 \\
Chronocoulometry, charge vs. dose & $0.625-2.5$ & $2.6 \mathrm{mC}$ per $1 \mathrm{mg} / \mathrm{mL}$ & 0.31 \\
Chronocoulometry, slope (charge/s) vs. dose & $0.312-2.5$ & $0.25 \mathrm{mC} / \mathrm{s}$ per $1 \mathrm{mg} / \mathrm{mL}$ & 0.15 \\
\hline
\end{tabular}

a The limit of detection (LOD) was calculated using the equation LOD $=3 \mathrm{~s} / \mathrm{m}$, where $\mathrm{s}=$ the standard deviation of the lowest concentration measured and $\mathrm{m}=$ the slope of the linear region for the dose-response curve [25].
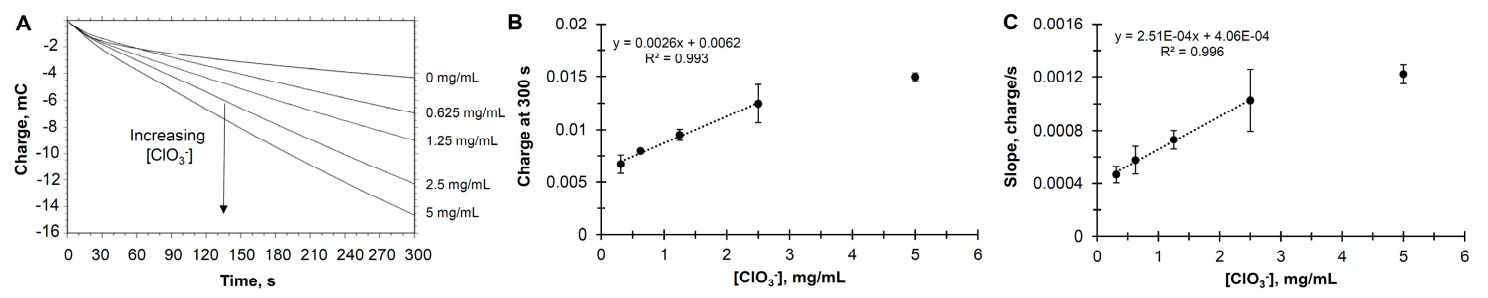

Figure 4. (A) Chronocoulometry with increasing $\left[\mathrm{KClO}_{3}\right]$ for the paper-based electrochemical probe containing $\left[\mathrm{PMo}_{11} \mathrm{VO}_{40}\right]^{5-}$ measured at $-1 \mathrm{~V}$ vs. $\mathrm{Ag} / \mathrm{AgCl}$. (B) Dose-response curve, $\mathrm{mC}$ vs. $\left[\mathrm{KClO}_{3}\right]$ (C) Dose-response curve, slope $(\mathrm{mC} / \mathrm{s})$ vs. $\left[\mathrm{KClO}_{3}\right]$.

With an LOD of $0.083 \mathrm{mg} / \mathrm{mL}$, our paper based-probe is less sensitive compared to our earlier work using $\mathrm{CV}$ for chlorate detection with a multilayer film containing $\left[\mathrm{PMo}_{11} \mathrm{VO}_{40}\right]^{5-}$ on indium tin oxide $(\mathrm{LOD}=0.027 \mathrm{mg} / \mathrm{mL}$ ) [1]. However, the paper-based probe provides a more tractable construction of the electrode probe containing the catalyst. Both electrochemical techniques are less sensitive compared to elaborate instrumentation using amperometric (LOD $=0.00014 \mathrm{mg} / \mathrm{mL}$ ) [16] or spectrometric $(\mathrm{LOD}=0.0005 \mathrm{mg} / \mathrm{mL}$ ) [17] assays based on stopped flow injection techniques for the detection of chlorate in soils. 


\subsection{Selectivity}

Experiments were performed to see if the paper-based probe would be selective between chlorate and nitrite, since POMs are also catalytic for the reduction of nitrite [26]. Chronoamperometry experiments were performed in which nitrite or chlorate was added in different sequences to the paper-based probe over the course of the experiment. In these experiments, the working electrode was held at a fix potential of $-0.7 \mathrm{~V}$ vs. $\mathrm{Ag} / \mathrm{AgCl}$ and the current was recorded as a function of time. As shown in the blue trace in Figure $5 \mathrm{~A}$, at $100 \mathrm{~s}$ the addition of nitrite yields a reduction signal that is about half as strong as the signal for chlorate (red trace). At $200 \mathrm{~s}$, the addition of chlorate after the addition of nitrite does not increase the signal significantly (blue trace), and the addition of nitrite after the addition of chlorate decreases the signal (red trace). These results suggest that nitrite will block the catalytic reduction for chlorate.
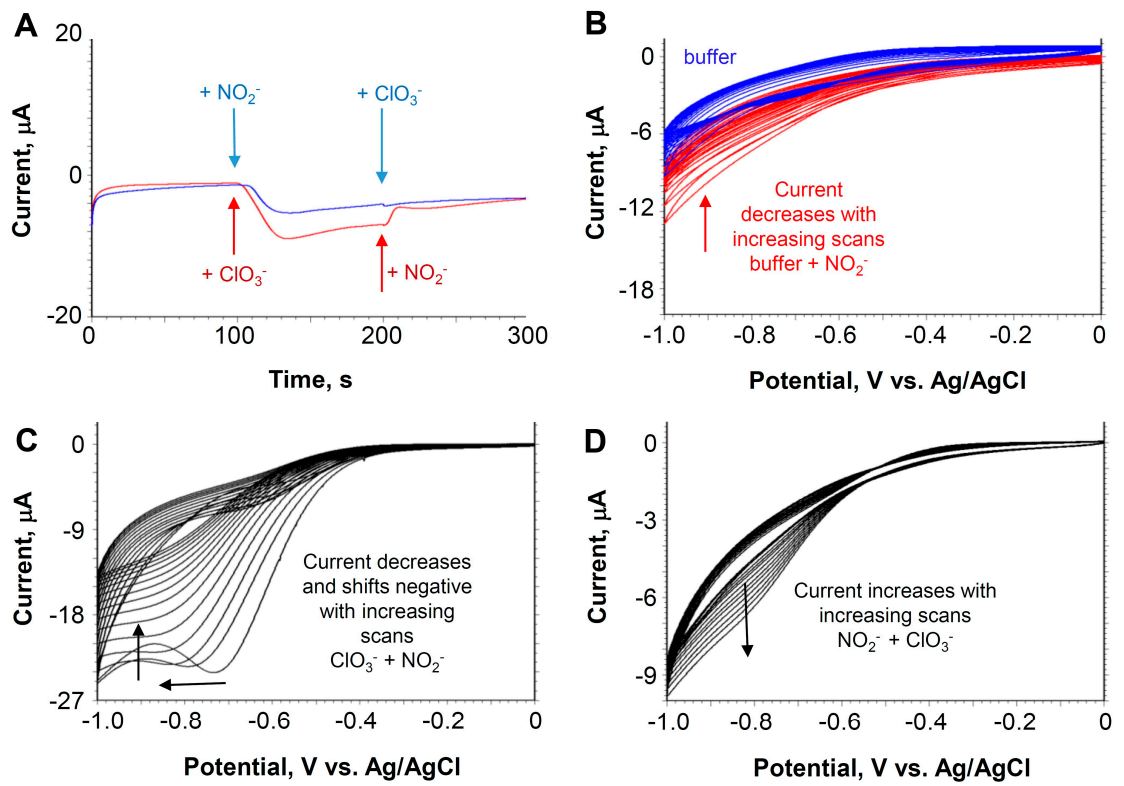

Figure 5. (A) Chronoamperometry experiments at the paper-based probe in which nitrite or chlorate $(10 \mathrm{mM})$ is added in different sequences to the paper-based probe over the course of the experiment. Potential of the working electrode $=-0.7 \mathrm{~V}$ vs. $\mathrm{Ag} / \mathrm{AgCl}$. (B) Cyclic voltammograms of the paper-based probe with the addition of $10 \mathrm{mM}$ sodium nitrite. (C) Addition of $10 \mathrm{mM}$ sodium nitrite after the addition and CV equilibration of $10 \mathrm{mM}$ chlorate. (D) Addition of $10 \mathrm{mM}$ potassium chlorate after the addition and CV equilibration of $10 \mathrm{mM}$ sodium nitrite. For (B-D), scan rate $=100 \mathrm{mV} / \mathrm{s}$.

The same effect can also be shown in CV experiments. As shown in Figure 5B, with the addition of nitrite, there was an increase in current from a featureless $\mathrm{CV}$ for the initial signal of the reduction current, which decays to buffer levels. As shown in Figure 5C, after the chlorate signal has reached a steady state, showing a typical catalytic peak current, the addition of nitrite decreases the current and the peak shifts negative into a broad featureless catalytic trace similar to the CV present in the nitrite-only result. As shown in Figure 5D, adding chlorate after the addition of nitrite only slightly increases the catalytic reduction current. In both chronoamperometry and voltammetry experiments, it is clear that nitrite blocks the catalytic reduction of chlorate in the paper-based probe. On the other hand, nitrite and chlorate yield clear and distinguishable catalytic CV signatures, which when measured separately can be used for identification.

\subsection{Soil Assay}

We developed a simple CV assay for soils in which the paper can also serve as a filter for sampling, highlighting our theme of practical field work. In our assay, several soil types were spiked with $\mathrm{KClO}_{3}$ 
and directly added on top of the filter paper with buffer for a direct measurement with no sample preparation. The response from the soil was compared to the same conditions and concentrations with a buffer only sample (no soil), and a percent recovery was calculated from the ratio. Example voltammograms are shown in Figure 6A. Three soil types were tested and the assays were repeated in triplicate, with the results shown in Figure 6B. The percent recoveries are low for all soil types suggesting that the simple assay does not directly measure all the chlorate in spiked soil. This suggests that chlorate could be adsorbed onto the soil, so the buffer would have to "extract" it first to solubilize it. In addition, the chlorate would have to diffuse through a tortuous path to the electrode to be detected. The simple assay is not quantitative, but should be adequate for qualitative identification for bulk analysis in which soil has been contaminated at low percentages of chlorate at the sub-mg level in which optical methods would be challenged.
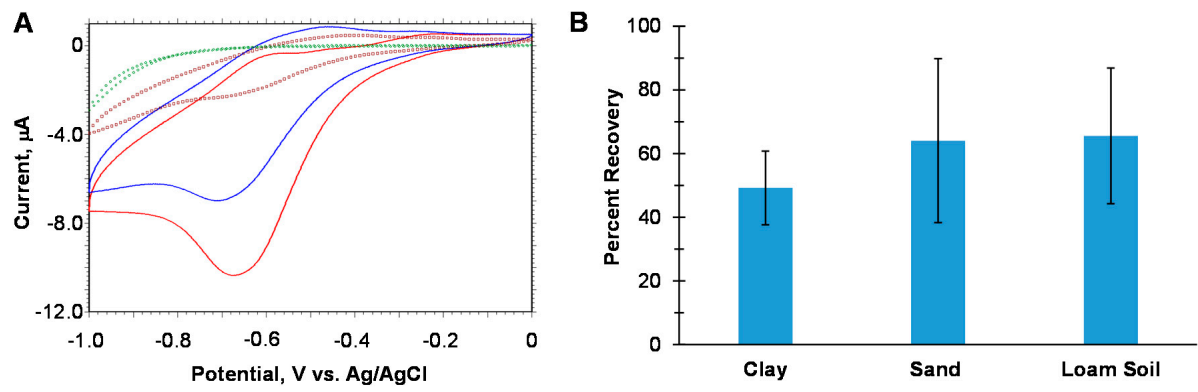

Figure 6. (A) Example cyclic voltammograms of different chlorate samples recorded at $100 \mathrm{mV} / \mathrm{s}$ for the paper-based electrochemical probe containing $0.45 \mathrm{mg}\left[\mathrm{PMo}_{11} \mathrm{VO}_{40}\right]^{5-}$. The red $\mathrm{CV}$ is the chlorate response without sand and the blue $\mathrm{CV}$ is with sand. The trace with the brown squares is the $\mathrm{CV}$ without chlorate and the trace with the green circles is without catalyst. Conditions $=100 \mathrm{mg}$ soil with $250 \mu \mathrm{g}$ of $\mathrm{KClO}_{3}$ and a total volume of buffer in the assay $=180 \mu \mathrm{L}$, total concentration of $\left[\mathrm{KClO}_{3}\right]=1.4 \mathrm{mg} / \mathrm{mL}$. Scans 29 and 30 are displayed for each CV. (B) Percent recovery of the sensor response of different soil samples.

\subsection{Digital Simulation}

Interestingly, in the CV studies, an additional peak centered between -0.5 and $-0.6 \mathrm{~V}$ begins to grow at high chlorate concentration in the anodic sweep of the CVs (Figure 1B). The direction of the current is in a negative direction, indicating a reduction. This result was not seen with any of the other salts and was only seen at high concentrations of chlorate. One possible mechanism for this phenomenon is the inactivation of the electrocatalyst at more negative reduction potential, after which, in the reverse sweep, the catalyst is regenerated, producing a cathodic peak in the reverse scan.

An attempt to simulate this phenomenon with a simplified model that is strictly qualitative was made. The simplification was necessary to keep the simulation tractable. In our model, A, which represents the polyoxometalate anion, becomes reduced to B at a mild reduction potential. The rate is slow, shifting the peak to more negative values. The active form of the electrocatalyst, $\mathrm{B}$, then reduces the chlorate anion and is regenerated back to A, completing the catalytic step.

To generate the observed phenomenon, a competing reaction was added to the model in which a second reduction at a more negative potential generates $C$, which is an inactive form of the electrocatalyst. In the reverse sweep, $\mathrm{B}$ is then regenerated from $\mathrm{C}$ and catalysis proceeds, generating the additional catalytic cathodic peak. The model is simulated in Figure 7 and overlaid with a background subtracted data set at $\left[\mathrm{KClO}_{3}\right]=5 \mathrm{mg} / \mathrm{mL}$. While this model is simplistic and does not include multiple electron and atom transfer steps, it does generally reproduce the observed phenomenon and since the second cathodic catalytic peak in the return sweep is not seen with other salts, the phenomenon could be used as a descriptive signature for chlorate identification. We choose not to speculate about the nature of $C$ here, but are pursuing further studies related to its identification and characterization for future publications. 


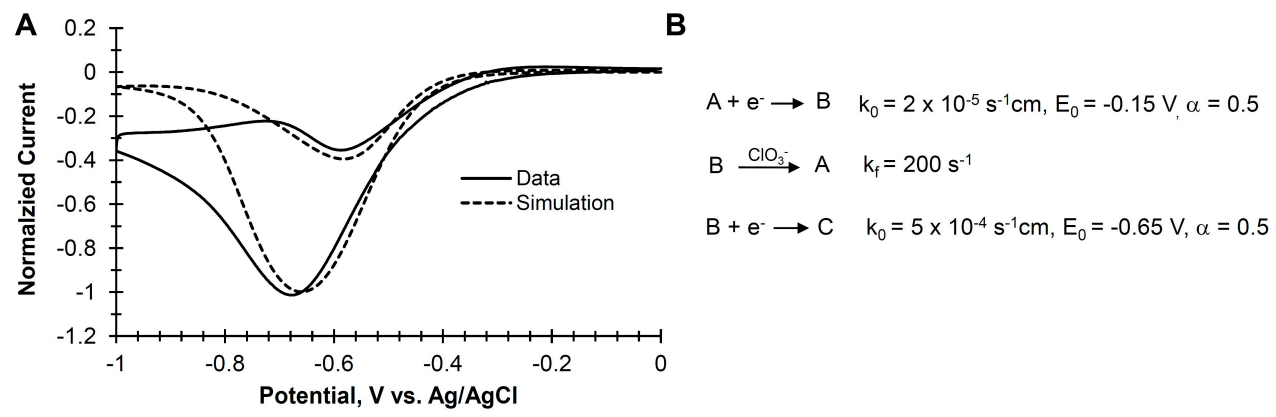

Figure 7. (A) Baseline subtracted cyclic voltammogram (solid line) at $\left[\mathrm{KClO}_{3}\right]=5 \mathrm{mg} / \mathrm{mL}$ compared to the simulated model (dotted line). (B) The electrochemical model used in the digital simulation.

\section{Conclusions}

The use of a paper-based probe impregnated with the vanadium-containing polyoxometalate anion, $\left[\mathrm{PMo}_{11} \mathrm{VO}_{40}\right]^{5-}$, on top of screen-printed carbon electrodes via the electrochemical method described herein represents a simple technique for the detection of chlorate in solution. This method can be utilized in numerous electrochemical systems. For $\left[\mathrm{PMo}_{11} \mathrm{VO}_{40}\right]^{5-}$-impregnated filter paper spiked with chlorate, the LOD for the $\mathrm{CV}$ assay was $0.083 \mathrm{mg} / \mathrm{mL}(\mathrm{S} / \mathrm{N}>3)$. This performance was reproducible for $\left[\mathrm{PMo}_{11} \mathrm{VO}_{40}\right]^{5-}$-impregnated paper stored under ambient conditions for at least 8 months prior to use. A simple soil assay in which different soil types spiked with $\mathrm{KClO}_{3}$ were directly added to the probe without any pre-sample preparation was also tested. While this simple soil assay precluded quantitative analysis, a qualitative "yes or no" answer obtained with bulk powder on soil surfaces is adequate for UAV-based chlorate identification applications. In addition, the observed phenomenon of the second cathodic catalytic peak in the return sweep, which could be used as a descriptive signature for chlorate identification, highlights the simplicity of the electrochemical assay for field work.

Acknowledgments: This work was supported by the US Naval Research Laboratory and the Office of Naval Research for funding through an NRL 6.2 Program.

Author Contributions: L.C.S.-L. performed the experiments and was involved in the preparation of the manuscript. D.Z. performed the electrochemical simulations. W.J.D. synthesized the catalyst. D.A.S. conceived the use of a paper probe. S.A.T. designed the experiments, analyzed the data, and prepared the manuscript.

Conflicts of Interest: The authors declare no conflict of interest.

\section{References}

1. Trammell, S.A.; Shriver-Lake, L.C.; Dressick, W.J. Statistical evaluation of an electrochemical probe for the detection of chlorate. Sens. Actuators B Chem. 2017, 239, 951-961. [CrossRef]

2. Ryan, P.; Zabetakis, D.; Stenger, D.A.; Trammell, S.A. Integrating paper chromatography with electrochemical detection for the trace analysis of tnt in soil. Sensors 2015, 15, 17048-17056. [CrossRef] [PubMed]

3. Erickson, J.S.; Shriver-Lake, L.C.; Zabetakis, D.; Stenger, D.A.; Trammell, S.A. A simple and inexpensive electrochemical assay for the identification of nitrogen containing explosives in the field. Sensors 2017, 17, 1769. [CrossRef] [PubMed]

4. Almaviva, S.; Chirico, R.; Nuvoli, M.; Palucci, A.; Schnurer, F.; Schweikert, W. A new eye-safe uv raman spectrometer for the remote detection of energetic materials in fingerprint concentrations: Characterization by pca and roc analyzes. Talanta 2015, 144, 420-426. [CrossRef] [PubMed]

5. Guo, Y.H.; Wang, X.T.; Miao, B.; Li, Y.; Yao, W.R.; Xie, Y.F.; Li, J.D.; Wu, D.M.; Pei, R.J. An aunps-functionalized algan/gan high electron mobility transistor sensor for ultrasensitive detection of tnt. RSC Adv. 2015, 5, 98724-98729. [CrossRef]

6. Jamil, A.K.M.; Izake, E.L.; Sivanesan, A.; Agoston, R.; Ayoko, G.A. A homogeneous surface-enhanced raman scattering platform for ultra-trace detection of trinitrotoluene in the environment. Anal. Methods 2015, 7, 3863-3868. [CrossRef] 
7. Komarova, N.V.; Andrianova, M.S.; Gubanova, O.V.; Kuznetsov, E.V.; Kuznetsov, A.E. Development of a novel enzymatic biosensor based on an ion-selective field effect transistor for the detection of explosives. Sens. Actuators B-Chem. 2015, 221, 1017-1026. [CrossRef]

8. Giordano, B.C.; Field, C.R.; Andrews, B.; Lubrano, A.; Woytowitz, M.; Rogers, D.; Collins, G.E. Trace explosives vapor generation and quantitation at parts per quadrillion concentrations. Anal. Chem. 2016, 88, 3747-3753. [CrossRef] [PubMed]

9. Wang, J. Electrochemical sensing of explosives. Electroanalysis 2007, 19, 415-423. [CrossRef]

10. Burns, E.A. Spectrophotometric determination of chlorate impurities in ammonium perchlorateDetermination of reducing and oxidizing impurities in hydrochloric acid. Anal. Chem. 1960, 32, 1800-1803. [CrossRef]

11. Urone, P.; Bonde, E. Colorimetric determination of chlorates in well waters. Anal. Chem. 1960, 32, $1666-1668$. [CrossRef]

12. Trautwein, N.L.; Guyon, J.C. Spectrophotometric determination of chlorate ion. Anal. Chim. Acta 1968, 41, 275-285. [CrossRef]

13. Chiswell, B.; Kellerlehmann, B. Spectrophotometric method for the determination of chlorite and chlorate. Analyst 1993, 118, 1457-1459. [CrossRef]

14. Hosseini, S.G.; Pourmortazavi, S.M.; Gholivand, K. Spectrophotometric determination of chlorate ions in drinking water. Desalination 2009, 245, 298-305. [CrossRef]

15. Rowe, A.A.; Bonham, A.J.; White, R.J.; Zimmer, M.P.; Yadgar, R.J.; Hobza, T.M.; Honea, J.W.; Ben-Yaacov, I.; Plaxco, K.W. Cheapstat: An open-source, "do-it-yourself" potentiostat for analytical and educational applications. PLoS ONE 2011, 6, e23783. [CrossRef] [PubMed]

16. Tue-Ngeun, O.; Jakmunee, J.; Grudpan, K. A novel stopped flow injection-amperometric procedure for the determination of chlorate. Talanta 2005, 68, 459-464. [CrossRef] [PubMed]

17. Somnam, S.; Grudpan, K.; Jakmunee, J. Stopped-flow injection spectrophotometric method for determination of chlorate in soil. MAEJO Int. J. Sci. Technol. 2008, 2, 383-390.

18. Unoura, K.; Iwashita, A.; Itabashi, E.; Tanaka, N. Catalytic effects of chlorate ions on the electrode-reaction processes of 12-molybdophosphate and 12-molybdosilicate. Bull. Chem. Soc. Jpn. 1984, 57, 597-598. [CrossRef]

19. Sadakane, M.; Steckhan, E. Electrochemical properties of polyoxometalates as electrocatalysts. Chem. Rev. 1998, 98, 219-237. [CrossRef] [PubMed]

20. Fernandes, D.M.; Teixeira, A.; Freire, C. Multielectrocatalysis by layer-by-layer films based on pararosaniline and vanadium-substituted phosphomolybdate. Langmuir 2015, 31, 1855-1865. [CrossRef] [PubMed]

21. Mialane, P.; Marrot, J.; Riviere, E.; Nebout, J.; Herve, G. Structural characterization and magnetic properties of sandwich-type tungstoarsenate complexes. Study of a mixed-valent $\mathrm{V}^{\mathrm{IV}}{ }_{2} / \mathrm{V}^{\mathrm{V}}$ heteropolyanion. Inorg. Chem. 2001, 40, 44-48. [PubMed]

22. Contant, R.; Abbessi, M.; Thouvenot, R.; Herve, G. Dawson type heteropolyanions. 3. Syntheses and 31p, $51 \mathrm{v}$, and $183 \mathrm{w} \mathrm{nmr}$ structural investigation of octadeca(molybdo-tungsto-vanado)diphosphates related to the [h2p2w12o48]12-anion. Inorg. Chem. 2004, 43, 3597-3604. [CrossRef] [PubMed]

23. Lopez, X.; Bo, C.; Poblet, J.M. Electronic properties of polyoxometalates: Electron and proton affinity of mixed-addenda keggin and wells-dawson anions. J. Am. Chem. Soc. 2002, 124, 12574-12582. [CrossRef] [PubMed]

24. Himeno, S.; Ishio, N. A voltammetric study on the formation of $\mathrm{v}(\mathrm{v})$ - and v(iv)-substituted molybdophosphate(v) complexes in aqueous solution. J. Electroanal. Chem. 1998, 451, 203-209. [CrossRef]

25. Harris, D.C. Quantitative Chemical Analysis, 7th ed.; W.H. Freeman and Co.: New York, NY, USA, 2007.

26. Boussema, F.; Haddad, R.; Ghandour, Y.; Belkhiria, M.S.; Holzinger, M.; Maaref, A.; Cosnier, S. Polyoxometalate $\left[\mathrm{PMo}_{11} \mathrm{O}_{39}\right]^{7-} /$ carbon nanocomposites for sensitive amperometric detection of nitrite. Electrochim. Acta 2016, 222, 402-408. [CrossRef]

(C) 2018 by the authors. Licensee MDPI, Basel, Switzerland. This article is an open access article distributed under the terms and conditions of the Creative Commons Attribution (CC BY) license (http:/ / creativecommons.org/licenses/by/4.0/). 